OPEN ACCESS

Edited by:

Sarah Mansfield

AgResearch, New Zealand

Reviewed by:

Joop J. A. Van Loon,

Wageningen University and Research Centre, Netherlands

Johan A. Stenberg,

Swedish University of Agricultural

Sciences, Sweden

*Correspondence:

Carolyn Mitchell

carolyn.mitchell@hutton.ac.uk

Specialty section:

This article was submitted to

Crop Science and Horticulture,

a section of the journal

Frontiers in Plant Science

Received: 19 February 2016

Accepted: 15 July 2016

Published: 29 July 2016

Citation:

Mitchell C, Brennan RM, Graham J and Karley AJ (2016) Plant Defense against Herbivorous Pests: Exploiting Resistance and Tolerance Traits for Sustainable Crop Protection.

Front. Plant Sci. 7:1132.

doi: 10.3389/fpls.2016.01132

\section{Plant Defense against Herbivorous Pests: Exploiting Resistance and Tolerance Traits for Sustainable Crop Protection}

\author{
Carolyn Mitchell1*, Rex M. Brennan², Julie Graham ${ }^{2}$ and Alison J. Karley ${ }^{1}$ \\ ' Ecological Sciences, The James Hutton Institute, Dundee, UK, ${ }^{2}$ Cell and Molecular Sciences, The James Hutton Institute, \\ Dundee, UK
}

Interactions between plants and insect herbivores are important determinants of plant productivity in managed and natural vegetation. In response to attack, plants have evolved a range of defenses to reduce the threat of injury and loss of productivity. Crop losses from damage caused by arthropod pests can exceed 15\% annually. Crop domestication and selection for improved yield and quality can alter the defensive capability of the crop, increasing reliance on artificial crop protection. Sustainable agriculture, however, depends on reduced chemical inputs. There is an urgent need, therefore, to identify plant defensive traits for crop improvement. Plant defense can be divided into resistance and tolerance strategies. Plant traits that confer herbivore resistance typically prevent or reduce herbivore damage through expression of traits that deter pests from settling, attaching to surfaces, feeding and reproducing, or that reduce palatability. Plant tolerance of herbivory involves expression of traits that limit the negative impact of herbivore damage on productivity and yield. Identifying the defensive traits expressed by plants to deter herbivores or limit herbivore damage, and understanding the underlying defense mechanisms, is crucial for crop scientists to exploit plant defensive traits in crop breeding. In this review, we assess the traits and mechanisms underpinning herbivore resistance and tolerance, and conclude that physical defense traits, plant vigor and herbivore-induced plant volatiles show considerable utility in pest control, along with mixed species crops. We highlight emerging approaches for accelerating the identification of plant defensive traits and facilitating their deployment to improve the future sustainability of crop protection.

Keywords: agro-ecosystem, arthropod, crop improvement, insect, natural enemy, trophic interactions

\section{INTRODUCTION}

Domestication of agricultural crops, estimated at 2500 species globally (Meyer et al., 2012), has involved artificial selection of desirable traits that enhance yield and quality of the harvested product. While breeding for agronomic targets in high input environments has successfully increased global crop productivity (Lynch, 2007), it has tended to produce modern crop varieties with relatively low levels of diversity (Khush, 2001). This reduced genetic diversity could limit the availability of varieties adapted for crop production under non-optimal conditions. Plant defensive 
traits can be lacking or expressed weakly in domesticated plants as a consequence of selection for other desirable traits (Chen et al., 2015). This poses a particular challenge for improving the sustainability of crop production as it suggests that modern varieties would perform poorly in low input systems with restricted pesticide use. While crop productivity has increased over the past century, combined global crop losses due to weeds, pests and diseases can be up to $40 \%$ (Oerke and Dehne, 2004). Across all vegetation systems, foliage, sap and root feeding herbivores remove $>20 \%$ of net plant productivity (Agrawal, 2011). These losses occur despite increased pesticide use over recent decades (Oerke and Dehne, 2004), highlighting the need to develop sustainable approaches for pest control with less reliance on chemical inputs. To address concerns regarding human health, environmental safety and pesticide resistance, plant defensive traits could be exploited more widely in crop protection strategies.

Focusing on arthropod herbivores as pests, this review seeks, first, to summarize the plant defense strategies that have been documented in agricultural crops, second, to consider the potential utility of different types of crop defense, and, third, to highlight opportunities and technologies for improving the identification and deployment of plant defensive traits, particularly to achieve sustainable pest management under a changing environment.

\section{PLANT DEFENSE STRATEGIES TOWARD ARTHROPOD PESTS}

Plants have been successful in colonizing most environments and their success is due in part to their ability to resist or tolerate herbivore attack (Hanley et al., 2007). In a crop protection context, the system developed by Stout (2013) is particularly useful in differentiating between two plant defense strategies and the underpinning traits: resistance and tolerance. Resistance occurs when plant structural or chemical traits deter herbivore feeding and thus minimize the amount of herbivore damage experienced by the plant. Tolerance occurs when plant traits reduce the negative effects of herbivore damage on crop yield. This differentiation can allow defensive traits to be matched to the risk posed by the target pest: i.e., a high risk pest that should be reduced to low densities or eliminated vs. a low risk pest that can be tolerated within certain abundance thresholds. To identify suitable plant traits for crop protection against specific pests, we need a basic understanding of the mechanisms underpinning defensive traits, and how environmental conditions affect trait expression.

An important consideration is the extent to which defensive traits will provide durable pest control. Since plant resistance traits typically deter herbivore feeding, they are likely to impose a strong selection pressure on the herbivore to overcome plant resistance (Janzen, 1980). In contrast, plant tolerance traits are often assumed to have no effect on herbivore fitness, and therefore unlikely to impose selection on the herbivore (Strauss and Agrawal, 1999; Stowe et al., 2000). Stinchcombe (2002) challenges this assumption, suggesting that in some circumstances tolerance traits could influence herbivore performance, but few studies have investigated this possibility, particularly in a crop protection context. Either way, resistance traits are likely to impose a stronger selection pressure due to more severe impacts on pest fitness, suggesting that tolerance traits will be more stable (Weis and Franks, 2006) with greater chance of providing durable pest control.

\section{RESISTANCE TRAITS AND MECHANISMS}

The mechanism by which specific plant resistance traits deter herbivore feeding is likely to vary with the stage of insect establishment that they influence. Here, we summarize traits that are known to promote crop resistance to herbivores by (1) deterring pest landing, (2) preventing attachment and feeding, and (3) reducing plant palatability (Table 1).

\section{Chemical Deterrence of Pest Settling and Feeding}

Herbivore feeding and oviposition can induce plant defense, including emission of herbivore induced plant volatiles (HIPVs), which have been proposed as a new focus for crop pest resistance and biocontrol (Stenberg et al., 2015). Production of HIPVs signals herbivore presence that can attract natural enemies of the pest and even signal herbivore threat and induce defense responses in neighboring plants (e.g., Erb et al., 2015). A recent meta-analysis of HIPV studies (Rowen and Kaplan, 2016) concluded that domesticated plants tend to produce volatiles in larger quantities but of simpler composition compared to wild relatives (Chen et al., 2015; Rowen and Kaplan, 2016), suggesting that specific biosynthetic capabilities have been lost during crop breeding (Dicke, 2016). Wild relatives offer a genetic resource for reintroducing these traits into crops (Stenberg et al., 2015), and landraces can provide genetic variation in HIPV production and natural enemy attraction (e.g., parasitoids of maize stemborer: Tamiru et al., 2015). Engineering elevated volatile production into crop plants is feasible: for example, wheat plants modified to produce insect alarm pheromone both repelled aphids and attracted their natural enemies in controlled conditions, although this did not translate into improved aphid control in the field (Bruce et al., 2015).

'Priming' of plant defenses by cues that signal herbivore threat can allow rapid induction of plant defenses upon subsequent herbivore attack (Kim and Felton, 2013). Priming of inducible responses is an attractive proposition for crop breeding, allowing plant defense allocation to be balanced against the degree of herbivore pressure (Stenberg et al., 2015). The identity of plant elicitors and mechanisms of defense induction are emerging for several crop species (Huffaker et al., 2013; Huffaker, 2015), opening up opportunities for exploiting priming and defense induction traits in crop breeding (Stenberg et al., 2015).

\section{Physical Barriers}

Plant structural traits (e.g., trichomes, spinescence, waxy cuticles, sclerophylly) can act as a physical barrier to arthropod 
TABLE 1 | Examples of traits and underpinning mechanisms conferring crop resistance or tolerance to target arthropod pests.

\begin{tabular}{|c|c|c|c|c|c|}
\hline Defense strategy & Mechanism & Trait and mode of action & Target pest & Crop host & Reference \\
\hline \multirow[t]{12}{*}{ Resistance } & $\begin{array}{l}\text { (1) Chemical deterrence } \\
\text { of pest settling and } \\
\text { feeding }\end{array}$ & $\begin{array}{l}\text { Engineered elevated production of } \\
\text { repellent alarm pheromone }\end{array}$ & Myzus persicae & Triticum aestivum & Bruce et al., 2015 \\
\hline & & $\begin{array}{l}\text { HIPV-induced attraction of maize } \\
\text { stemborer parasitoids }\end{array}$ & Chilo partellus & Cotesia sesamiae & Tamiru et al., 2015 \\
\hline & & $\begin{array}{l}\text { Plant elicitor peptides induce plant } \\
\text { defenses that impair Beet armyworm } \\
\text { growth and attract its parasitoids }\end{array}$ & Spodoptera exigua & Zea mays & Huffaker et al., 2013 \\
\hline & $\begin{array}{l}\text { (2) Physical barriers to } \\
\text { pest attachment, } \\
\text { feeding and oviposition }\end{array}$ & $\begin{array}{l}\text { Epicuticular waxes differentially affect } \\
\text { herbivore attachment }\end{array}$ & $\begin{array}{l}\text { Sitona lineatus, } \\
\text { Acyrthosiphum } \\
\text { pisum }\end{array}$ & Pisum sativum & $\begin{array}{l}\text { White and Eigenbrode, } \\
2000\end{array}$ \\
\hline & & $\begin{array}{l}\text { Leaf surface waxes contribute to } \\
\text { reduced performance of diamondback } \\
\text { moth on cabbage }\end{array}$ & Plutella xylostella & Brassica sp. & $\begin{array}{l}\text { Hariprasad and van } \\
\text { Emden, } 2010\end{array}$ \\
\hline & & $\begin{array}{l}\text { Glandular trichomes reduce mite } \\
\text { movement }\end{array}$ & Tetranychus urticae & $\begin{array}{l}\text { Fragaria } x \\
\text { ananassa }\end{array}$ & Figueiredo et al., 2013 \\
\hline & & $\begin{array}{l}\text { Glandular trichomes reduce growth of } \\
\text { corn earworm } \\
\text { Non glandular trichomes impair } \\
\text { Colorado potato beetle feeding and } \\
\text { growth }\end{array}$ & $\begin{array}{l}\text { Helicoverpa zea } \\
\text { Leptinotarsa } \\
\text { decemlineata }\end{array}$ & $\begin{array}{l}\text { Solanum } \\
\text { lycopersicum }\end{array}$ & Tian et al., 2012 \\
\hline & & $\begin{array}{l}\text { High density of non glandular trichomes } \\
\text { prevent mite oviposition on raspberry }\end{array}$ & Tetranychus urticae & Rubus idaeus & $\begin{array}{l}\text { Graham et al., 2014; } \\
\text { Karley et al., } 2016\end{array}$ \\
\hline & $\begin{array}{l}\text { (3) Reduced plant } \\
\text { palatability }\end{array}$ & $\begin{array}{l}\text { Gramine alkaloid decreased aphid } \\
\text { feeding, growth and survival }\end{array}$ & $\begin{array}{l}\text { Rhopalasiphum } \\
\text { padi }\end{array}$ & Hordeum vulgare & Zúñiga and Corcuera, 1986 \\
\hline & & $\begin{array}{l}\text { Benzoxazinoid synthesis decreased } \\
\text { aphid growth and survival }\end{array}$ & $\begin{array}{l}\text { Rhopalasiphum } \\
\text { padi }\end{array}$ & Zea mays & Ahmad et al., 2011 \\
\hline & & $\begin{array}{l}\text { Aliphatic and indole glucosinolates } \\
\text { reduced larval consumption and growth } \\
\text { and slowed development on mature } \\
\text { plants }\end{array}$ & $\begin{array}{l}\text { Mamestra } \\
\text { brassicae } \\
\text { Pieris rapae }\end{array}$ & $\begin{array}{l}\text { Brassica oleracea } \\
\text { var. acephala }\end{array}$ & $\begin{array}{l}\text { Santolamazza-Carbone } \\
\text { et al., } 2016\end{array}$ \\
\hline & & $\begin{array}{l}\text { Diterpenoid kauralexins deter feeding of } \\
\text { corn borer larvae }\end{array}$ & Ostrinia nubilalis & Zea mays & Schmelz et al., 2011 \\
\hline \multirow[t]{3}{*}{ Tolerance } & $\begin{array}{l}\text { (1) Photosynthesis and } \\
\text { growth }\end{array}$ & Stimulate growth & $\begin{array}{l}\text { Amphorophora } \\
\text { idaei }\end{array}$ & Rubus ideaus & $\begin{array}{l}\text { Johnson et al., 2012; } \\
\text { Karley et al., } 2016\end{array}$ \\
\hline & & Increased root vigor & Lepidiota stigma & $\begin{array}{l}\text { Saccharum } \\
\text { officinarum }\end{array}$ & Allsop and Cox, 2002 \\
\hline & (2) Phenology & Delayed allocation to roots & $\begin{array}{l}\text { Diabrotica virgifera } \\
\text { virgifera }\end{array}$ & Zea mays & Robert et al., 2015 \\
\hline
\end{tabular}

pest attachment, feeding and oviposition; the plant cuticle and trichome density are two traits of particular focus in crop protection. Epicuticular waxes form a slippery film or crystals that prevent pests from attaching to the plant surface (White and Eigenbrode, 2000), ovipositing or feeding (Hariprasad and van Emden, 2010). Trichomes can prevent pest attachment and limit pest movement on crops (e.g., Tian et al., 2012; Figueiredo et al., 2013). While the effect of glandular trichomes is likely to have a chemical basis (see Reduced Plant Palatability, below), non-glandular trichomes act as a physical deterrent: oviposition by the generalist phytophagous mite, Tetranychus uticae, was significantly reduced on raspberry genotypes with high leaf trichome densities (Karley et al., 2016), and with identification of underlying genetic markers, this trait has potential utility in breeding for mite control (Graham et al., 2014). Trichomes can also have indirect negative (Michalska, 2003) and positive effects (Dai et al., 2010) on the target pest through their impact on the behavior of herbivore natural enemies. For example, abundance of the predatory mite Typhlodromus pyri on grape was associated positively with the presence of leaf trichomes, while its prey, the European red mite, favored grape varieties with low trichome density (Loughner et al., 2008). Trichomes tend to be more effective against insects that are small relative to trichome size; additionally, trichomes tend to deter sap feeding or leaf chewing insects to a greater extent than those feeding within plant tissues (Hanley et al., 2007). 


\section{Reduced Plant Palatability}

Plant compounds that are toxic or impair gut function in arthropods, produced constitutively or induced by herbivore damage, can enhance crop resistance to pests; examples include alkaloids (Zúñiga and Corcuera, 1986), benzoxazinoids (Ahmad et al., 2011), glucosinolates (Santolamazza-Carbone et al., 2016), and terpenoids (Schmelz et al., 2011). Plant breeding has tended to select against high levels of defensive compounds (Chen et al., 2015) due to their detrimental effects on crop quality for consumption. Targeted expression of defensive compounds in non-harvested organs (e.g., gossypol in vegetative structures of cotton; Palle et al., 2013) might allow tissue-specific engineering of chemical resistance into crops, although indirect effects of plant quality on biocontrol by natural enemies should be tested (Ågren et al., 2012). Another intriguing avenue is through symbiosis between cereal grasses and Epichloë fungal endophytes, allowing crops to benefit from fungal production of insecticidal alkaloids (Simpson et al., 2014).

Many plants deposit granular minerals in tissues that deter insect attack and feeding. A well-known example is silica accumulation in grasses (up to $2-5 \%$ silica by mass: Massey et al., 2006), which is abrasive, damaging herbivore feeding structures, and reducing digestibility (Massey and Hartley, 2009). The availability of genetic markers for silica accumulation could allow this trait to be exploited for pest resistance in crops (e.g., in rice: Bryant et al., 2011).

\section{TOLERANCE TRAITS AND MECHANISMS}

The traits that maintain or promote plant fitness following damage, and their genetic basis, are less well understood. Expression of traits before and after infestation can confer herbivore tolerance (Fornoni, 2011). Plant tolerance traits (Table 1) are classically grouped into those that alter (i) physiological processes such as photosynthetic activity and growth, (ii) phenology, and (iii) use of stored nutrients (Strauss and Agrawal, 1999; Stowe et al., 2000; Tiffin, 2000). We focus on the first two categories as there are few examples of using stored nutrient reserves as a tolerance strategy, although storage organs are important for plant recovery from damage and offer an effective strategy against unpredictable herbivore attack if there is no tradeoff with plant productivity (Strauss and Agrawal, 1999).

\section{Photosynthesis and Growth}

In many plant species, partial defoliation leads to increased photosynthetic rate in the remaining plant tissues (Strauss and Agrawal, 1999; Retuerto et al., 2004), suggesting that compensatory photosynthesis is a common physiological response to leaf damage (Tiffin, 2000). However, increased photosynthetic activity is not a universal response to herbivory and does not always drive compensatory growth, possibly due to resource diversion into resistance traits (Tiffin, 2000). Herbivore identity can determine whether changes in photosynthetic rate and growth occur: for example, compensatory photosysthesis is induced by several insect herbivores of soybean and drybean, but not by Mexican bean beetle (Peterson et al., 1998). By contrast, aphid feeding on the perennial crop red raspberry frequently stimulates plant growth and influences nitrogen physiology (Johnson et al., 2012), which could reflect tolerance to aphid herbivory through increased plant vigor (Karley et al., 2016). Similarly in sugarcane, clonal variation in tolerance to rootfeeding whitegrub correlated with increased plant vigor (Allsop and Cox, 2002). Plant vigor can provide tolerance to herbivory in a range of plant species (Price, 1991); higher abundance and fitness of many insect herbivore groups on vigorous host plants (Cornelissen et al., 2008) could reflect increased ability of vigorous plants to tolerate attack. Although plant vigor is likely to be controlled by multiple loci, quantitative trait loci (QTL) studies have identified genetic markers for vigor (e.g., root and shoot vigor in raspberry: Graham et al., 2011, 2014) that could be deployed in crop breeding.

Activation of dormant buds after removal or damage to flowering or vegetative meristems is a further type of compensatory growth mechanism that allows plants to recover from herbivore attack that could be exploited in crop species with multiple meristems (Tiffin, 2000). In some circumstances, growth overcompensation is observed, which might be an attractive trait for improving crop tolerance in fertile agricultural conditions (Pilson, 2000), although any impact on the quality of the harvested product would need to be assessed.

\section{Phenology}

Delayed growth, flower and fruit production following herbivore damage could promote herbivore tolerance by postponing plant development until the threat of attack has passed (Tiffin, 2000). For example, delayed resource allocation to roots is thought to underpin tolerance of western corn rootworm in herbivoretolerant maize (Robert et al., 2015). The utility of these traits will depend on whether delayed development has a negative impact on yield and quality if the delay leads to crop flowering, pollination or ripening during non-optimal conditions.

\section{SELECTING TRAITS TO OPTIMIZE PLANT DEFENSE: OPPORTUNITIES AND CHALLENGES}

Matching defensive traits to herbivore types to optimize pest control will depend on the nature of damage inflicted by the pest, whether direct feeding damage, removal of resources, visual spoiling or vectoring plant disease (Figure 1). Resistance traits are more desirable for maintaining disease vectors below threshold infestation densities. Tolerance traits are likely to be useful against non-vector pests that typically cause damage by removing resources and reducing plant growth (Figure 1A), although this has to be balanced against the possibility of pest spillover to neighboring crops or between cropping cycles. An important consideration is whether the target defensive trait has a negative impact on populations of beneficial organisms, particularly natural enemies of the pest. For example, while high trichome densities can reduce abundance of insect pests on cotton, trichomes can also impair the searching efficiency 


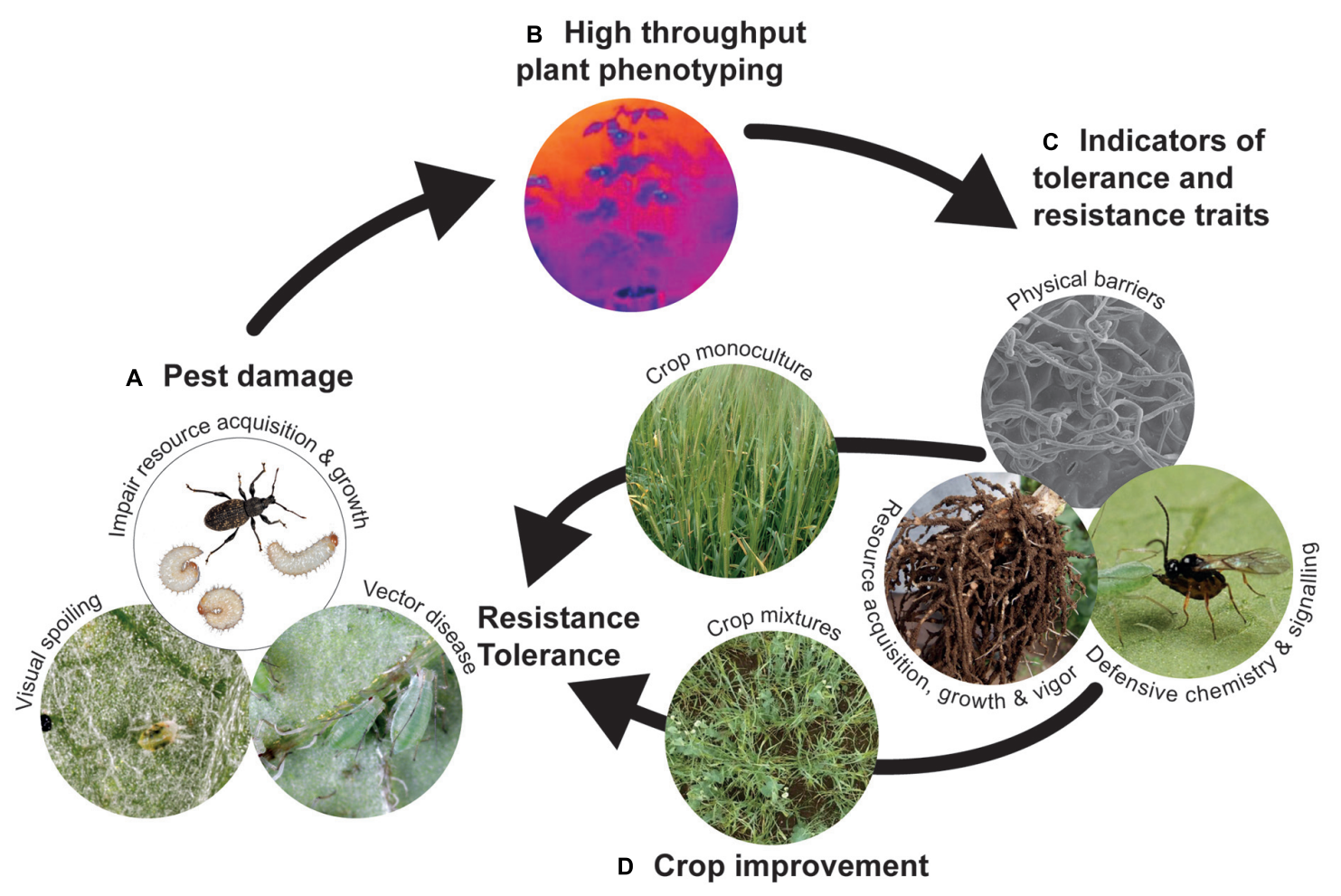

FIGURE 1 | Proposed strategy for improving crop protection against target arthropod pests. (A) Identify the appropriate defense strategy (resistance or tolerance) depending on the type of damage and threat posed by the target pest; (B) develop high throughput phenotyping (HTP) technologies, particularly new imaging methods, for screening large plant populations to $\mathbf{( C )}$ identify appropriate indicators of resistance and tolerance traits; indicators could include reflectance properties that provide information about leaf surface characteristics and physical barriers, thermal and absorption data that provides information about stomatal conductance and water status, and therefore indicate photosynthetic activity and plant vigor, and absorption/reflectance data that characterizes leaf pigment composition and metabolic changes underpinning defense signaling (e.g., attracting natural enemies); (D) traditionally, desirable traits are characterized in germplasm monocultures, but phenotyping traits for use in crop mixtures is a potential route for durable pest control, particularly under environmental change.

of herbivore natural enemies (Hagenbucher et al., 2013); by contrast, leafminers on tomato and their parasitoids are deterred by leaf trichomes, but trichomes and HIPVs have antagonistic effects on insect behavior (Wei et al., 2013). In some situations, incorporating plant traits that enhance natural enemy searching behavior might be more beneficial than enhancing pest resistance traits (Schmidt, 2014; Stenberg et al., 2015).

Technological advances in large-scale plant genotyping can accelerate selection of germplasm with desirable traits (Anderson and Mitchell-Olds, 2011), including herbivore defense. The rate-limiting step now resides in the ability to conduct high throughput phenotyping (HTP) to characterize desirable traits in large plant populations (Figure 1B). Imaging methodologies offer exciting opportunities for large-scale visualization of plant populations in controlled and field conditions, allowing semi-automated collection of light signals from the plant surface across a wide spectrum of wavelengths ranging between visible and infra-red (Fahlgren et al., 2015). Image-extracted traits provide information on canopy temperature, pigment composition and water status that can be linked to targeted measures of plant performance (Fahlgren et al., 2015). HTP approaches using imaging are already providing genetic markers for crop performance under abiotic stress (e.g., Prashar et al., 2013), and there is significant potential for applying imaging techniques to phenotype plant responses to insect pests (Goggin et al., 2015). For example, imaging methods could provide non-destructive indicators of physiological processes, such as stomatal conductance and water status, leaf pigment composition or photosynthetic activity, or plant vigor (Figure 1C) that indicate genotypic differences in ability to tolerate or resist insect pest attack above and belowground.

While studies of plant defensive traits frequently focus on a single trait and target pest, the underlying genetic control and expression of traits is likely to involve a suite of traits (Agrawal, 2011) expressed to defend against multiple pests above- and below-ground. Depending on the dominant crop pests, it might be feasible to focus on a single defensive trait, such as silica accumulation, which is effective against a range of herbivore types (Reynolds et al., 2009; Guntzer et al., 2012). Although there is surprisingly little evidence for trade-offs in plant investment between multiple defenses (Koricheva et al., 2004), understanding the genetic control of multiple traits remains a significant challenge for crop breeders. An alternative approach is to take advantage of defensive traits associated with different crop types grown as cultivar- or species-mixtures (Figure 1D). Plant 
diversification in crop systems often enhances natural enemy populations, suppresses arthropod pest populations and reduces crop damage (Letourneau et al., 2011) by providing a more complex habitat and heterogeneous resource for natural enemies, decreasing the density of preferred host plants, and interfering with host plant location and/or quality for herbivores (Jonsson et al., 2008; Letourneau et al., 2011). A good example of the latter effect is the negative impact of onions co-cropped with potato on attraction of potato aphids (Ninkovic et al., 2013). Increasing plant diversity in crop systems can confer additional benefits of yield stability and resource-use efficiency (Brooker et al., 2015). While there are many examples of the benefits of cultivating crop mixtures, particularly the 'push-pull' systems developed in sub-Saharan Africa for pest biocontrol (Pickett et al., 2014), there is significant opportunity for breeding crops with traits that optimize performance in mixtures (Ren et al., 2014).

\section{CONCLUSION AND FUTURE PERSPECTIVES}

Crop domestication over recent decades has focused on plant traits that improve yield, enhance quality for human consumption and make the crop more amenable to existing cropping methods (Chen et al., 2015). Now, however, there is increasing focus on improving the sustainability of agriculture by reducing reliance on pesticides and other chemical inputs (War et al., 2012). From the studies highlighted here, there is considerable potential to exploit HIPVs, physical defenses and plant vigor to protect crops (and crop mixtures) against focal pests and to promote activity of natural enemies. A major uncertainty, however, is the durability of crop protection under a changing climate, which is anticipated to increase pest pressures on crops. Elevated temperatures are likely to accelerate insect development and increase the number of insect generations each season (DeLucia et al., 2012), elevated $\mathrm{CO}_{2}$ could decrease herbivore abundance but increase consumption

\section{REFERENCES}

Agrawal, A. A. (2011). Current trends in the evolutionary ecology of plant defence. Funct. Ecol. 25, 420-432. doi: 10.1111/j.1365-2435.2010.01796.x

Ågren, G. I., Stenberg, J. A., and Björkman, C. (2012). Omnivores as plant bodyguards - A model of the importance of plant quality. Basic Appl. Ecol. 13, 441-448. doi: 10.1016/j.baae.2012.07.005

Ahmad, S., Veyrat, N., Gordon-Weeks, R., Zhang, Y., Martin, J., Smart, L., et al. (2011). Benzoxazinoid metabolites regulate innate immunity against aphids and fungi in maize. Plant Physiol. 157, 317-327. doi: 10.1104/pp.111. 180224

Allsop, P. G., and Cox, M. C. (2002). Sugarcane clones vary in their resistance to sugarcane whitegrubs. Aust. J. Agric. Res. 53, 1111-1136. doi: 10.1071/ AR02035

Anderson, J. T., and Mitchell-Olds, T. (2011). Ecological genetics and genomics of plant defences: evidence and approaches. Funct. Ecol. 25, 312-324. doi: 10.1111/j.1365-2435.2010.01785.x

Brooker, R. W., Bennett, A. E., Cong, W.-F., Daniell, T. J., George, T. S., Hallett, P. D., et al. (2015). Improving intercropping: a synthesis of research in agronomy, plant physiology and ecology. New Phytol. 206, 107-117. doi: 10.1111/nph.13132
(Stiling and Cornelissen, 2007), while intermittent water stress can enhance performance in certain herbivore guilds (Huberty and Denno, 2004). The effect of climate factors, individually or in concert, on expression of plant defense traits is uncertain. Elevated temperature and $\mathrm{CO}_{2}$ promote plant growth and volatile production, and can modulate defense signaling (DeLucia et al., 2012), which might strengthen expression of these tolerance/resistance traits. Conversely, these climate factors tend to reduce plant nutritional quality and decrease allocation to defensive compounds and physical structures, thus promoting plant consumption by herbivores (Stiling and Cornelissen, 2007; DeLucia et al., 2012), which suggests that crop protection from these physical and chemical resistance traits might be compromised under a changing climate. Applying imaging methods for HTP of target traits under conditions that mimic future climates (e.g., Rasmann et al., 2014), in parallel with optimizing crop defensive traits in mixtures, should assist crop scientists in identifying traits and trait combinations that are resilient to a changing environment, and that can be deployed as part of an integrated approach for sustainable crop protection.

\section{AUTHOR CONTRIBUTIONS}

The article was conceived by all authors, researched by $\mathrm{CM}$ and written by $\mathrm{CM}$ and $\mathrm{AK}$, with corrections contributed by JG and RB.

\section{ACKNOWLEDGMENTS}

Authors were funded by the Scottish Government within the RESAS Programme Environmental Change (2011-2016) conducted at the James Hutton Institute. Images in Figure 1 were provided by $\mathrm{AK}$ and $\mathrm{CM}$ as part of work conducted for the Physical Fruit project (TSB153), and by Pete Iannetta and Kirsty Black at the James Hutton Institute as part of work conducted for the Beans4Feeds Project (TSB101096).

Bruce, T. J. A., Aradottir, G. I, Smart, L. E., Martin, J. L., Caulfield, J. C., and Doherty, A. (2015). The first crop plant genetically engineered to release an insect pheromone for defence. Nature 5:11183. doi: 10.1038/srep11183

Bryant, R., Proctor, A., Hawkridge, M., Jackson, A., Yeater, K., Counce, P., et al. (2011). Genetic variation and association mapping of silica concentration in rice hulls using a germplasm collection. Genetica 139, 1383-1398. doi: 10.1007/s10709-012-9637-x

Chen, Y. H., Gols, R., and Benrey, B. (2015). Crop domestication and its impact on naturally selected trophic interactions. Annu. Rev. Entomol. 60, 35-58. doi: 10.1146/annurev-ento-010814-020601

Cornelissen, T., Fernandes, G. W., and Vasconcellos-Neto, J. (2008). Size does matter: variation in herbivory between and within plants and the plant vigor hypothesis. Oikos 117, 1121-1130. doi: 10.1111/j.2008.0030-1299.16588.x

Dai, H., Wang, Y., Du, Y., and Ding, J. (2010). Effects of plant trichomes on herbivores and predators on soybeans. Insect Sci. 17, 406-413. doi: 10.1111/j.1744-7917.2009.01305.x

DeLucia, E. H., Nabity, P. D., Zavala, J. A., and Berenbaum, M. R. (2012). Climate change: resetting plant-insect interactions. Plant Physiol. 160, 1677-1685. doi: 10.1104/pp.112.204750

Dicke, M. (2016). Induced plant volatiles: plant body odours structuring ecological networks. New Phytol. 210, 10-12. doi: 10.1111/nph.13896 
Erb, M., Veyrat, N., Robert, C. A. M., Xu, H., Frey, M., Ton, J., et al. (2015). Indole is an essential herbivore-induced volatile priming signal in maize. Nat. Commun. 6:6273. doi: $10.1038 /$ ncomms7273

Fahlgren, N., Gehan, M. A., and Baxter, I. (2015). Lights, camera, action: highthroughput plant phenotyping is ready for a close-up. Curr. Opin. Plant Biol. 24, 93-99. doi: 10.1016/j.pbi.2015.02.006

Figueiredo, A. S. T., Resende, J. T. V., Morales, R. G. F., Gonçalves, A. P. S., and Da Silva, P. R. (2013). The role of glandular and non-glandular trichomes in the negative interactions between strawberry cultivars and spider mite. Arthropod Plant Interact. 7, 53-58. doi: 10.1007/s11829-0129218-z

Fornoni, J. (2011). Ecological and evolutionary implications of plant tolerance to herbivory. Funct. Ecol. 25, 399-407. doi: 10.1111/j.1365-2435.2010. 01805.x

Goggin, F. L., Lorence, A., and Topp, C. N. (2015). Applying high-throughput phenotyping to plant-insect interactions: picturing more resistant crops. Curr. Opin. Insect Sci. 9, 69-76. doi: 10.1016/j.cois.2015.03.002

Graham, J., Hackett, C. A., Smith, K., Karley, A. J., Mitchell, C., Roberts, H., et al. (2014). Genetic and environmental regulation of plant architectural traits and opportunities for pest control in raspberry. Ann. Appl. Biol. 165, 318-328. doi: 10.1111/aab.12134

Graham, J., Hackett, C. A., Smith, K., Woodhead, M., MacKenzie, K., Tierney, I., et al. (2011). Towards an understanding of the nature of resistance to Phytophthora root rot in red raspberry. Theor. Appl. Genet. 123, 585-601. doi: 10.1007/s00122-011-1609-5

Guntzer, F., Keller, C., and Meunier, J. D. (2012). Benefits of plant silicon for crops: a review. Agron. Sustain. Dev. 32, 201-213. doi: 10.1007/s13593-011-0039-8

Hagenbucher, S., Olson, D. M., Ruberson, J. R., Wäckers, F. L., and Romeis, J. (2013). Resistance mechanisms against arthropod herbivores in cotton and their interactions with natural enemies. Crit. Rev. Plant Sci. 32, 458-482. doi: 10.1080/07352689.2013.809293

Hanley, M. E., Lamont, B. B., Fairbanks, M. M., and Rafferty, C. M. (2007). Plant structural traits and their role in anti-herbivore defence. Perspect. Plant Ecol. Evol. Syst. 8, 157-178. doi: 10.1016/j.ppees.2007.01.001

Hariprasad, K. V., and van Emden, H. F. (2010). Mechanisms of partial plant resistance to diamondback moth (Plutella xylostella) in brassicas. Int. J. Pest Manag. 56, 15-22. doi: 10.1080/09670870902980834

Huberty, A. F., and Denno, R. F. (2004). Plant water stress and its consequences for herbivorous insects: a new synthesis. Ecology 85, 1383-1398. doi: 10.1890/ 03-0352

Huffaker, A. (2015). Plant elicitor peptides in induced defense against insects. Curr. Opin. Insect Sci. 9, 44-50. doi: 10.1016/10.1016/j.cois.2015.06.003

Huffaker, A., Pearce, G., Veyrat, N., Erb, M., Turlings, T. C. J., Sartor, R., et al. (2013). Plant elicitor peptides are conserved signals regulating direct and indirect antiherbivore defense. Proc. Natl. Acad. Sci. U.S.A. 110, 5707-5712. doi: 10.1073/pnas. 1214668110

Janzen, D. H. (1980). When is it coevolution? Evolution 34, 611-612. doi: $10.2307 / 2408229$

Johnson, S. N., Young, M. W., and Karley, A. J. (2012). Protected raspberry production alters aphid-plant interactions but not aphid population size. Agric. For. Entomol. 14, 217-224. doi: 10.1111/j.1461-9563.2011.00561.x

Jonsson, M., Wratten, S. D., Landis, D. A., and Gurr, G. M. (2008). Recent advances in conservation biological control of arthropods by arthropods. Biol. Control 45, 172-175. doi: 10.1016/j.biocontrol.2008.01.006

Karley, A. J., Mitchell, C., Brookes, C., McNicol, J., O’Neill, T., Roberts, H., et al. (2016). Exploiting physical defence traits for crop protection: leaf trichomes of Rubus idaeus have deterrent effects on spider mites but not aphids. Ann. Appl. Biol. 168, 159-172. doi: 10.1111/aab.12252

Khush, G. S. (2001). Green revolution: the way forward. Nat. Rev. Genet. 2, 815-822. doi: 10.1038/35093585

Kim, J., and Felton, G. W. (2013). Priming of antiherbivore defensive responses in plants. Insect Sci. 20, 273-285. doi: 10.1111/j.1744-7917.2012.01584.x

Koricheva, J., Nykanen, H., and Gianoli, E. (2004). Meta-analysis of trade-offs among plant antiherbivore defenses: are plants jacks-of-all-trades, masters of all? Am. Nat. 163, E64-E75. doi: 10.1086/382601

Letourneau, D. K., Armbrecht, I., Rivera, B. S., Lerma, J. M., Carmona, E. J., Daza, M. C., et al. (2011). Does plant diversity benefit agroecosystems? A synthetic review. Ecol. Appl. 21, 9-21. doi: 10.1890/09-2026.1
Loughner, R., Goldman, K., Loeb, G., and Nyrop, J. (2008). Influence of leaf trichomes on predatory mite (Typhlodromus pyri) abundance in grape varieties. Exp. Appl. Acarol. 45, 111-122. doi: 10.1007/s10493-008-9183-5

Lynch, J. P. (2007). Roots of the second green revolution. Aust. J. Bot. 55, 493-512. doi: $10.1071 /$ bt06118

Massey, F. P., Ennos, A. R., and Hartley, S. E. (2006). Silica in grasses as a defence against insect herbivores: contrasting effects on folivores and a phloem feeder. J. Anim. Ecol. 75, 595-603. doi: 10.1111/j.1365-2656.2006.01082.x

Massey, F. P., and Hartley, S. E. (2009). Physical defences wear you down: progressive and irreversible impacts of silica on insect herbivores. J. Anim. Ecol. 78, 281-291. doi: 10.1111/j.1365-2656.2008.01472.x

Meyer, R. S., DuVal, A. E., and Jensen, H. R. (2012). Patterns and processes in crop domestication: an historical review and quantitative analysis of 203 global food crops. New Phytol. 196, 29-48. doi: 10.1111/j.1469-8137.2012. 04253.x

Michalska, K. (2003). Climbing of leaf trichomes by eriophyid mites impedes their location by predators. J. Insect Behav. 16, 833-844. doi: 10.1023/b:joir.0000018323.55232.31

Ninkovic, V., Dahlin, I., Vucetic, A., Petrovic-Obradovic, O., Glinwood, R., and Webster, B. (2013). Volatile exchange between undamaged plants - a new mechanism affecting insect orientation in intercropping. PLoS ONE 8:e69431. doi: 10.1371/journal.pone.0069431

Oerke, E. C., and Dehne, H. W. (2004). Safeguarding production - losses in major crops and the role of crop protection. Crop Prot. 23, 275-285. doi: 10.1016/j.cropro.2003.10.001

Palle, S. R., Campbell, L. M., Pandeyal, D., Puckhaber, L., Tollack, L. K., Marcel, S., et al. (2013). RNAi-mediated Ultra-low gossypol cottonseed trait: performance of transgenic lines under field conditions. Plant Biotechnol. J. 11, 296-304. doi: 10.1111/pbi.12013

Peterson, R. K. D., Higley, L. G., Haile, F. J., and Barrigossi, J. A. F. (1998) Mexican bean beetle (Coleoptera: Coccinellidae) injury affects photosynthesis of Glycine max and Phaseolus vulgaris. Environ. Entomol. 27, 373-381. doi: $10.1093 /$ ee/27.2.373

Pickett, J. A., Woodcock, C. M., Midega, C. A. O., and Khan, Z. R. (2014). Push-pull farming systems. Curr. Opin. Biotechnol. 26, 125-132. doi: 10.1016/j.copbio.2013.12.006

Pilson, D. (2000). The evolution of plant response to herbivory: simultaneously considering resistance and tolerance in Brassica rapa. Evol. Ecol. 14, 457-489. doi: 10.1023/A:1010953714344

Prashar, A., Yildiz, J., McNicol, J. W., Bryan, G. J., and Jones, H. G. (2013). Infra-red thermography for high throughput field phenotyping in Solanum tuberosum. PLoS ONE 8:e65816. doi: 10.1371/journal.pone.0065816

Price, P. W. (1991). The plant vigor hypothesis and herbivore attack. Oikos 62, 244-251. doi: 10.2307/3545270

Rasmann, S., Pellissier, L., Defossez, E., Jactel, H., and Kunstler, G. (2014). Climatedriven change in plant-insect interactions along elevation gradients. Funct. Ecol. 28, 46-54. doi: 10.1111/1365-2435.12135

Ren, W., Hu, L., Zhang, J., Sun, C., Tang, J., Yuan, Y., et al. (2014). Can positive interactions between cultivated species help to sustain modern agriculture? Front. Ecol. Environ. 12, 507-514. doi: 10.1890/130162

Retuerto, R., Fernandez-Lema, B., Rodriguez, R., and Obeso, J. R. (2004). Increased photosynthetic performance in holly trees infested by scale insects. Funct. Ecol. 18, 664-669. doi: 10.1111/j.0269-8463.2004.00889.x

Reynolds, O. L., Keeping, M. G., and Meyer, J. H. (2009). Silicon-augmented resistance of plants to herbivorous insects: a review. Ann. Appl. Biol. 155, 171-186. doi: 10.1111/j.1744-7348.2009.00348.x

Robert, C. A. M., Schirmer, S., Barry, J., Wade French, B., Hibbard, B. E., and Gershenzon, J. (2015). Belowground herbivore tolerance involves delayed overcompensatory root regrowth in maize. Entomol. Exp. Appl. 157, 113-120. doi: 10.1111/eea.12346

Rowen, E., and Kaplan, I. (2016). Eco-evolutionary factors drive induced plant volatiles: a meta-analysis. New Phytol. 210, 284-294. doi: 10.1111/nph.13804

Santolamazza-Carbone, S., Sotelo, T., Velasco, P., and Cartea, M. E. (2016). Antibiotic properties of the glucosinolates of Brassica oleracea var. acephala similarly affect generalist and specialist larvae of two lepidopteran pests. J. Pest Sci. 89, 195-206. doi: 10.1007/s10340-015-0658-y

Schmelz, E. A., Kaplan, F., Huffaker, A., Dafoe, N. J., Vaughan, M. M., Ni, X., et al. (2011). Indetity, regulation, and activity of inducible diterpenoid 
phytoalexins in maize. Proc. Natl. Acad. Sci. U.S.A. 108, 5455-5460. doi: $10.1073 /$ pnas. 1014714108

Schmidt, R. A. (2014). Leaf structures affect predatory mites (Acari: Phytoseiidae) and biological control: a review. Exp. Appl. Acarol. 62, 1-17. doi: 10.1007/s10493-013-9730-6

Simpson, W. R., Faville, M. J., Moraga, R. A., Williams, W. M., McManus, M. T., and Johnson, R. D. (2014). Epichloë fungal endophytes and the formation of synthetic symbioses in Hordeeae ( $=$ Triticeae) grasses. J. Syst. Evol. 52, 794-806. doi: 10.1111/jse.12107

Stenberg, J. A., Heil, M., Ahman, I., and Bjorkman, C. (2015). Optimizing crops for biocontrol of pests and disease. Trends Plant Sci. 20, 698-712. doi: 10.1016/j.tplants.2015.08.007

Stiling, P., and Cornelissen, T. (2007). How does elevated carbon dioxide (CO2) affect plant-herbivore interactions? A field experiment and meta-analysis of CO2-mediated changes on plant chemistry and herbivore performance. Glob. Change Biol. 13, 1823-1842. doi: 10.1111/j.1365-2486.2007.01392.x

Stinchcombe, J. (2002). Can tolerance traits impose selection on herbivores? Evol. Ecol. 16, 595-602. doi: 10.1023/A:1021617418037

Stout, M. J. (2013). Re-evaluating the conceptual framework for applied research on host-plant resistance. Insect Sci. 20, 263-272. doi: 10.1111/1744-7917.12011

Stowe, K. A., Marquis, R. J., Hochwender, C. G., and Simms, E. L. (2000). The evolutionary ecology of tolerance to consumer damage. Annu. Rev. Ecol. Syst. 31, 565-595. doi: 10.1146/annurev.ecolsys.31.1.565

Strauss, S. Y., and Agrawal, A. A. (1999). The ecology and evolution of plant tolerance to herbivory. Trends Ecol. Evol. 14, 179-185. doi: 10.1016/s01695347(98)01576-6

Tamiru, A., Khan, Z. R., and Bruce, T. J. A. (2015). New directions for improving crop resistance to insects by breeding for egg induced defence. Insect Sci. 9, 51-55. doi: 10.1016/j.cois.2015.02.011

Tian, D., Tooker, J., Peiffer, M., Chung, S. H., and Felton, G. W. (2012). Role of trichomes in defense against herbivores: comparison of herbivore response to woolly and hairless trichome mutants in tomato (Solanum lycopersicum). Planta 236, 1053-1066. doi: 10.1007/s00425-012-1651-9

Tiffin, P. (2000). Mechanisms of tolerance to herbivore damage:what do we know? Evol. Ecol. 14, 523-536. doi: 10.1023/A:1010881317261

War, A. R., Paulraj, M. G., Ahmad, T., Buhroo, A. A., Hussain, B., Ignacimuthu, S., et al. (2012). Mechanisms of plant defense against insect herbivores. Plant Signal. Behav. 7, 1306-1320. doi: 10.4161/psb.21663

Wei, J., Yan, L., Ren, Q. I. N., Li, C., Ge, F., and Kang, L. E. (2013). Antagonism between herbivore-induced plant volatiles and trichomes affects tritrophic interactions. Plant Cell Environ. 36, 315-327. doi: 10.1111/j.13653040.2012.02575.x

Weis, A. E., and Franks, S. J. (2006). Herbivory tolerance and coevolution: an alternative to the arms race? New Phytol. 170, 423-425. doi: 10.1111/j.14698137.2006.01745.x

White, C., and Eigenbrode, S. D. (2000). Effects of surface wax variation in Pisum sativum on herbivorous and entomophagous insects in the field. Environ. Entomol. 29, 773-780. doi: 10.1603/0046-225x-29.4.773

Zúñiga, G. E., and Corcuera, L. J. (1986). Effect of gramine in the resistance of barley seedlings to the aphid Rhopalosiphum padi. Entomol. Exp. Appl. 40, 259-262. doi: 10.1111/j.1570-7458.1986.tb00509.x

Conflict of Interest Statement: The authors declare that the research was conducted in the absence of any commercial or financial relationships that could be construed as a potential conflict of interest.

Copyright (c) 2016 Mitchell, Brennan, Graham and Karley. This is an open-access article distributed under the terms of the Creative Commons Attribution License (CC BY). The use, distribution or reproduction in other forums is permitted, provided the original author(s) or licensor are credited and that the original publication in this journal is cited, in accordance with accepted academic practice. No use, distribution or reproduction is permitted which does not comply with these terms. 